\title{
Forgiveness and non-forgiveness: The defence of self-respect in alternative responses to wrongdoing
}

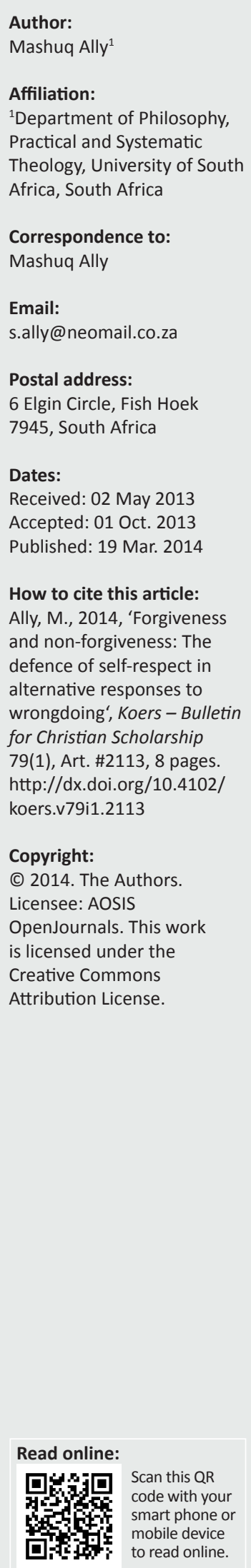

The focus of this article is on the notion that, whether in forgiveness or non-forgiveness, negative moral emotions towards a wrongdoer may remain extant and continue to generate memories of wrongdoing. This constitutes a kind of objection to the wrongdoing, even a sort of protest against it insofar as the wrongdoing seems to undermine the victim's sense of worth. I argue that certain non-retributive attitudes or emotions play under-appreciated roles in policing the boundaries of victims' self-respect and I attempt to explain what makes such attitudes or emotions - those that reflect the deepest concerns of victims of wrongdoing - centrally important. I defend the need for diverse responses that better fit the nuanced reactions amongst those who seek to come to terms with their hurt, especially those choosing not to forgive. Whatever stance is adopted, protecting one's self-respect remains the core value that victims of wrongdoing seek to defend.

Vergifnis en nie-vergewensgesindheid: Die verdediging van selfrespek in alternatiewe response op onreg. Hierdie artikel fokus op die opvatting dat negatiewe morele emosies teenoor ' $n$ kwaaddoener, hetsy in vergifnis of as gevolg van ' $n$ nie-vergewensgesindheid, kan voortduur en herinneringe van onreg aanwakker. Dit maak 'n tipe beswaar teen die onreg; selfs 'n soort protes daarteen omdat dit blyk dat die onreg die slagoffer se waardegevoel ondermyn. Ek voer aan dat die waarde van sekere nie-vergeldingsgesindhede of -emosies by die polisiëring van die grense van slagoffers se selfrespek onderskat word en probeer verduidelik waarom sulke gesindhede of emosies - wat die diepste bekommernisse van die slagoffers van onreg reflekteer - van sentrale belang is. Ek verdedig die behoefte aan diverse response wat beter pas by die genuanseerde reaksies onder diegene wat hulle seerkry probeer verwerk, veral diegene wat kies om nie te vergewe nie. Watter houding ook al aangeneem word, bly die beskerming van hul selfrespek die kernwaarde wat slagoffers van onreg probeer verdedig.

\section{Introduction}

Although many researchers focus on the advantages of forgiveness, only a few examine its negative or problematic features. In this article I shall argue that sometimes granting forgiveness to a wrongdoer may be morally questionable and may even be morally wrong. My purpose is to show that not forgiving can be as moral and beneficial in some situations as forgiving can be in others (Safer 1999). Drawing upon suggestions in recent forgiveness literature, I try to show that the existence of dissenting views concerning offences may in fact pave the way for such a stance: one which permits the victim to retain self-respect whilst excluding retributive motives.

My approach is as follows. In the first section I explore some of the issues occasioned by sentimentbased views of forgiveness to which my own variant belongs. My purpose is to introduce nonforgiveness as an intermediate position between forgiveness and unforgiveness (the retention of resentment and other retributive feelings in response to wrongdoing). I argue that certain non-retributive attitudes or emotions play under-appreciated roles in policing the boundaries of a victim's self-respect and attempt to explain what makes such attitudes or emotions - those that reflect the deepest concerns of victims of wrongdoing - centrally important. In the final two sections I examine how the victim's self-respect is implicated in diverse responses to wrongdoing.

\section{Non-retributive non-forgiveness as a variant of sentiment-based responses to wrongdoing}

The dominant view of forgiveness in the philosophical literature conceives it as the successful overcoming or setting aside of negative emotions - resentment and other retributive emotions with similar features - that are naturally directed towards a wrongdoer because of the wrongdoing (e.g., Allais 2008; Griswold 2007). I accept that forgiveness is the overcoming of retributive reactive attitudes, which include resentment and indignation, as well as other possible 
attitudes such as anger, malice, suspicion and contempt. However, the philosophical literature has tended to advocate what Lamb (2006:45) calls 'a hyper individualized notion of personal harm', suggesting that forgiveness cannot involve third parties (e.g., MacLachlan 2009; Pettigrove 2004; Radzik 2011). MacLachlan (2009) joins Lamb (2006) in pointing out that such an approach overlooks:

... both the role of group identities and identifications in situations of trauma and harms ignoring the often fragmented and multiple nature of our identities, as well as the ways in which we are always selves-in-relation to one another. (MacLachlan 2009:7)

She points out that whilst it may be conceptually tidy to describe scenarios of forgiveness as singular, isolated incidents, complete with a single, easily identifiable (and morally uncomplicated) 'victim' and 'wrongdoer', these paradigms bear very little resemblance to most actual situations in which we are called upon to forgive or be forgiven. If we treat 'hyper individualized' paradigms as normative frameworks for evaluating our more complicated moral experiences, we risk distorting the particularities of our moral reality. This is a view I endorse in seeking to explicate a more nuanced understanding of the relational aspects of responses to wrongdoing on the part of the many and varied parties concerned with it.

In contrast to the dominant position of overcoming retributive attitudes and emotions, a different sentiment-based account may hold, with Walker (2006:154-155), that there are many negative feelings that are 'likely to occur instead of or alongside angry ones', and that overcoming these can in some instances constitute forgiveness. According to Blustein (2010:589), sentiment-based accounts are characterised by the contention that forgiveness consists in a change of heart towards the offender, a change that does not leave resentment and other retributive feelings dominant.

How do we respond emotionally to being wrongfully harmed? Prima facie [at first sight], we are likely to experience emotions such as resentment, indignation and nuanced variants of these - hostile responses to being unjustifiably harmed. However, according to Walker (2006), the emotions that wrongdoing provokes are much more diverse than this:

Aside from anger, resentment, contempt, indignation, wrath, rage, hatred, scorn and vengefulness, being harmed wrongly can cause disappointment, hurt, heartbreak, sadness, despair, pessimism, mistrust, helplessness, and hopelessness; also disgust, anguish, shame, guilt, humiliation, fear, or terror. (p. 155)

This catalogue might appear to be a veritable potpourri of divergent attitudes and sentiments and certainly in need of justification. Forgiveness, it might be argued, involves overcoming or foreswearing only certain negative emotional responses to wrongdoing, those that are moral in nature whereas some of the emotions on Walker's list, like sadness and disappointment, do not seem to be of this sort. Blustein (2010:591) offers a clever way around this tricky issue. He suggests that the negative emotions that play a role in forgiveness are moral in the sense that they are partially constituted by the belief that one has been wrongfully harmed or done an unjustified and non-excused injury, and resentment is generally regarded as the central case. Ceteris paribus [all other things being unchanged or constant], should I be described as feeling disappointed at the betrayal of trust, this would count as a moral emotion because my friend would be justified in experiencing guilt or shame, for instance. So there seems to be no reason in principle to limit forgiveness to the overcoming or foreswearing of emotions of moral anger (Hughes 1997). Even repressing or successfully extinguishing retributive feelings might be insufficient to justify speaking of forgiveness if substantive feelings of 'disappointment, hurt, heartbreak, sadness' (to select arbitrarily from Walker's (2006) catalogue) remain.

However, as Blustein (2010) points out, it is also possible for some of the emotions on Walker's list to surface or remain after forgiveness has been achieved (and not merely as a kind of emotional residue without moral meaning), but - like negative emotions present before forgiveness - partially constituted by the belief that one has been wrongfully harmed:

Forgiveness need not, and commonly does not, wipe the emotional slate clean, eliminating all negative moral emotions. I can forgive you for your rudeness and continue to be hurt and saddened by your insensitivity; I can get over my anger at you for your insulting behaviour but nevertheless remain cautious and somewhat mistrustful of you because of it. (p. 592)

Now standard accounts tell us that forgiveness cannot have been achieved if resentment and other emotions of moral anger persist and no effort is made to moderate them. But if, following Walker, we can have cases in which it is some negative non-retributive emotion that has to be overcome for forgiveness to be achieved, this effectively blurs the distinction between the before and the after of forgiveness in terms of the emotions involved. Blustein (2010:592) suggests that there can be disappointment and hurt before forgiveness that impede the ability to forgive and that they can also remain after efforts at merely overcoming the harsher retributive sentiments have been successful. This raises the question of what the difference between pre- and post-forgiveness consists in when the same sorts of emotions are involved in both. These are problems that standard sentiment-based accounts of forgiveness do not have to deal with, since they draw a fairly sharp dividing line between the negative emotions that forgiveness overcomes and whatever emotions remain after forgiveness has been achieved.

A way of approaching this impasse, I suggest, is to adopt the stance of non-retributive non-forgiveness. In offering my own variant of sentiment-based accounts, I want to show that a victim can regain their damaged self-respect and identity without forgiving their wrongdoer, contrary to the orthodoxy of those who valorise forgiveness. So as to clarify the position that I am opposing, consider an earlier view of Holmgren (1993). In the course of her portrayal of the attitudes of the unconditional forgiver whose forgiveness does not compromise his/her self-respect, she claims that, whether the wrongdoer repents or not, the victim who reaches a state 
of genuine forgiveness exhibits a strong level of self-respect. $\mathrm{He} / \mathrm{she}$ is secure in his/her knowledge of his/her own worth and he/she does not allow herself/himself to be held in the grip of the wrongdoer's false opinion. Instead, he/she has the maturity to recognise the wrongdoer's confusion for what it is and to put it in proper perspective (ibid:346). This idealised description of the victim's capacity to retain his/her self-respect is at odds with much of the more recent literature on the topic, as I shall try to show in my final sections. ${ }^{1}$

Of course, negative emotions tend to lead towards inaccurate judgements, lessened concern for the other parties' preferences, and neglect of one's own instrumental goals. Feelings that may dissuade a victim from forgiving include distrust, anger, fear, contempt, embarrassment, shame, pride and disappointment. In many instances, these same negative emotions inhibit communication during mediation and make it difficult for parties to engage in constructive discussion (Shapiro 2002:72). On the other hand, non-forgiveness of whatever kind requires renewed focus upon a person's selfrespect. The harmed person can begin to live a better life as a result of actions and associations with good people in the human community, coming to see themselves as like them: a person who can care about others who are harmed, including themselves. When they receive the support of those who did not wrong or harm them, they learn that there is respect for themselves as persons, and not merely by virtue of them as victims. Learning to do this involves forging relationships with others as part of the process which enables them to transcend some of the limitations of victimhood. This provides a sound basis for the harmed person to live a good life, whilst strengthening communities through the fullest participation of people in their lives.

\section{The centrality of various non- retributive emotions in relation to self-respect}

It is a fact of human psychology that feelings of anger and resentment - feelings that often characterise a victim's immediate response to being harmed - tend to cool and may gradually subside even if the offender has not been forgiven. This is probably a reason for connecting forgiving with forgetting. However, non-forgiveness in the manner described implies that we no longer need to hold grudges we declare our independence of victimhood. Therapeutically speaking, it signifies breaking the cycle of pain and abuse, giving up the belief that the other person should hurt as much as we do, whilst discounting any further relationship with them. Nevertheless, I have argued, non-forgiveness is compatible with retaining a range of robust non-retributive negative feelings and attitudes towards the wrongdoer. The victim can, and often should, retain these feelings and attitudes in order to stand up for themselves and retain their self-respect.

1.I follow Dillon (1997:228) in her view that self-respect is not a discrete entity but is rather a complex of multiple-layered and inter-penetrating phenomena involving an emotionally charged interplay of self, others and institutions that begins long before we are capable of conceptualising relationships amongst them.
In contrast, there is widespread disagreement about precisely which feelings need to be overcome for forgiveness to take place. Everyone agrees that certain hostile feelings - such as resentment and indignation - are incompatible with forgiveness, but many (e.g., Murphy 1988; Roberts 1995) accept that the suggestion that all negative feelings must be overcome is too strong. For example, my continued disappointment that I have been betrayed by my best friend does not by itself show that I have not forgiven him. If, pace [with due deference] Blustein and many others, forgiveness does not entirely wipe the slate clean, feeling disappointed is compatible both with forgiveness and with non-forgiveness. What seems to have been missed is the central role that certain non-retributive emotions play in alternative responses to wrongdoing.

If I am disappointed in or disapprove of what you have done, I need not have any desire that you suffer harm for it. Hampton (1988) claims that negative moral emotions towards the perpetrator of the wrong may linger and may animate memories of wrongdoing, and when they do so, the emotions constitute a sort of continuing protest against or rejection of the diminution implied by that wrongdoing. ${ }^{2}$ This implies those negative emotions that are different from the retributive emotions generally attending the perception of being wronged play a role that has been insufficiently appreciated in both the forgiveness process and the post-forgiveness relations. Such negative non-retributive emotions often surface or linger after forgiveness has been achieved. I do not want to discount the regressive potential of such emotions in turning acts of forgiveness around. There is a need to acknowledge the danger that experiencing such emotions may be the occasion for recidivism by reviving and re-igniting the very retributive moral sentiments that the wrongdoing originally elicited. However, precisely because of such real dangers, the role of non-retributive emotions tends to be more peripheral in accounts of forgiveness. Consequently, philosophical accounts of such attitudes and emotions tend to under-moralise them. By under-moralising the content of these expressions of moral protest they have risked overlooking or covering over their ethical significance. Consider that, pace Blustein (2010) and Murphy (2003:19), hurt is a response that - at least potentially - deserves our moral attention as 'emotional testimony' to our moral values. Other attitudes can be taken seriously, insofar as they resemble this: that is, insofar as they protest the injury as an attack on their self-respect.

Blustein (2010:595) argues that the expression of such emotions as sadness, disappointment or grief over having been harmed by someone I trusted, for example, or the shame I might feel for having been so trusting of them - no less than my anger at them for this harm - can be a way of drawing moral attention to the harm. For Blustein such sentiments reveal the contours and importance of my sense of self-worth - the insistence

2.The protest need not come only from the victim, but also from the larger moral community. By the same token, as I argued above, it is possible to have a range of diverse responses over time to the wrongdoing by 'moral bystanders' - some forgiving diverse responses over time to the wrongdoing by 'moral bystanders' - some forgiving
- or, equally importantly, to refusing to forgive in a sense of solidarity with others - or, equally importantly, to refusing to forgive in a sense of solidarity with othe
in the same situation (see also MacLachlan 2009; Pettigrove 2004; Radzik 2011). 
on my right to respect. Communicating these emotions may have the effect of showing that one holds the offender responsible and blameworthy for what the person has done. In our different reactions to wrongdoing we reveal where the boundaries of our self-regard lie. They are different ways of pointing out to the offender that one holds their wrongdoing against them and that one will not merely gloss over acts that imply the diminishment of what one has the right to expect from them.

The point made here is that non-retributive negative emotions can (but need not always) function as distressed expressions of moral disapproval of how one has been treated. They reflect upon the offender for being the author of that treatment and it is as expressions of such disapproval that they serve to define and police the boundaries of one's self-respect.

However, drawing such boundaries may also be equivocal. Richards (1988) points out that:
... [i]t is possible for mistreatment to make one not angry or contemptuous but just very sad, if it is mistreatment at the hands of a loved one. Imagine, for example, that your grown son had badly let you down. This might make you angry, of course, but it might also make you feel deeply disappointed in him, instead. You are hurt that he should act in this way, not angry, not moved to hatred. (p. 78)

Contra Richards (1988), it may be that non-retributive negative emotions need not be overcome in order to forgive, although this may be a matter of the severity of such emotions. If I am so sad about the behaviour of my son that it hampers my relationship with him, I may need to overcome this sadness through forgiveness. However, if I am less saddened, this may be compatible with non-forgiveness and maintaining modified relations with him - a fact that by itself may give him pause for thought. Such considerations point towards the openness of interpersonal relationships and incline one towards thinking that neither forgiveness nor nonforgiveness can ever be prescribed. Nevertheless, despite the diversity of moral considerations, a core value - self-respect - may be found to underlie interpersonal relations - or, at least, so I hope to show.

\section{Self-respect and diverse responses to wrongdoing}

In turning now to the defence of self-respect in the different responses to wrongdoing, I want to argue that sometimes granting forgiveness to a wrongdoer may be morally questionable and may even be morally wrong. Of course, as Murphy (1988:33) points out, forgiveness is not always in my power: I can resolve and try the best I can to overcome resentment, but I will sometimes fail. Ought I to be blamed for this? Murphy insists that genuine forgiveness, if it is to be a moral virtue, must be based on moral reasons and so, it would seem, it must be a matter of choice. And yet, most of the time, we believe that we cannot choose what we feel - at least not directly, and perhaps not even indirectly.
We cannot make ourselves love someone because we think we ought to. Can we make ourselves forgive someone because we think they have separated themselves from their wrongful deed through, for instance, repenting? If not, harbouring resentment and even seeking revenge may require greater understanding than they are often accorded. ${ }^{3}$ Whilst it is not my intention to explore all possible positions on these matters, I want to argue that the existence of dissenting views concerning offences may in fact pave the way for such a stance: one which permits the victim to retain self-respect whilst not countenancing retributive steps that may lead to spiralling conflict.

In everyday life, transgressions cannot be avoided. Whilst relating with one another, we step on one another's toes. Relationships have the power to hurt as well as to enrich. There are many ways in every culture and society in which people easily excuse themselves from less serious offences. However, serious ones are rather different. For an offender, to acknowledge having caused harm and to repent is the usual precondition for forgiveness. On the other hand, responding as a victim of wrongdoing can take several different forms. Offended victims themselves may not need to wait to be approached in this way - they may take the initiative and approach the offender, holding out an olive branch. Of course, if the offence is particularly threatening to the victim's self-respect, they may seek other remedies, such as the rather regrettable if natural tit-for-tat response of retaliation. What needs to be borne in mind is the undoubted fact that it is indeed necessary for the victim to repudiate the offender's message that they do not count sufficiently for them to exercise proper restraint in their dealings. For Murphy (2003), the values of self-respect, self-defence and respect for the moral order are 'defended by resentment and threatened by hasty and uncritical forgiveness'. Resentment is a way to 'repudiate the message' (ibid:77) that the victim does not count as much as the offender and is consistent with some form of punishment. Murphy's (ibid:19) view 'takes the past very seriously and makes some of its evil irrevocable in human terms' (his emphasis).

In line with Murphy's (2003) view I accept that resentment is a negative feeling that the victim of a wrongdoing has towards an agent for harming them, that is, for committing culpable wrongdoing that the victim takes to have been directed against them. If the harm appears to be unintentional - or at least not done with ill-will - the victim does not feel resentment. Rather, they feel resentment when they take the harm to have been done without proper concern for their well-being, making the harm a wrong. In this way, the wrong constitutes harm on two counts: it is an injury and it is an insult to the victim, for it appears to the victim that the wrongdoer does not respect them appropriately (Murphy 1988:25). It is this insult that might lead the victim to view the wrongdoer's action as an assault on their self-respect. The 3.Even revenge has recently received qualified support. Rosebury (2008) claims that revenge is deserving of rational respect based on its standing outside morality as a choice by the revenger not to act morally but to obey other compelling motives. 
salient point is that: '... [ $t$ ] he self-respecting person thus also holds herself (though not others) to certain personal standards and expectations, the disappointment of which she would regard as a degrading self-betrayal'. (Dillon 1997:230)

Elsewhere (Ally 2005), I have defended the view that selfrespect has as its main feature that it requires a person to retain a susceptibility to feelings of shame when such feelings are appropriate. Here I would add a second significant feature: that it requires of a person that they respond typically with a variety of negative reactive attitudes - to actions that are disrespectful of them. Resentment usually performs such a function, but other responses such as indignation may be even more appropriate. It may even be the case that upon reflection one comes to see a disrespectful act as a way of curbing one's unacknowledged hubris and imbued with the appropriate desire for self-improvement overlook such an act. However, mutatis mutandis, someone who continues to endure insulting behaviour must be seen as lacking in appropriate self-respect, as indeed would someone who refused to accept responsibility for any hint of shame, as though they could always be entirely blameless (Taylor 1985:77-78).

To have and to retain self-respect is to remain susceptible to feelings of shame: knowing when these feelings are acceptable and then to own them. But in connecting such feelings to a 'way of being whose core is a deep appreciation of one's morally significant worth' (Dillon 1997:228), the selfrespecting person regards certain forms of thinking, feeling, desiring, and acting as befitting persons, and regards other forms as degrading, and they expect themselves (and other persons) to adhere to the former and avoid the latter. This is often seen as the hallmark of dignity, or self-worth in the sense that self-respect and dignity coincide precisely where we have accepted the reality of shame and yet been prepared to dissolve its most toxic effects in all manner of ways that accord us a sense of worth (Turner 1995:1072).

\section{Forgiveness, self-respect and the respect of others}

Failing to stand up for oneself is likely to decrease one's respect for oneself and one's sense of certainty about oneself and one's values. Forgiving too easily (with insufficient serious engagement with the wrongdoer concerning the damage they have wrought) practically always diminishes one's self-respect (Luchies et al. 2010). On the other hand, it is possible for forgiving to enhance one's self-respect. It may be thought that merely by repenting and requesting forgiveness a wrongdoer deserves to be forgiven. Certainly, in such instances, it is possible for forgiving to enhance one's self-respect. But what if the wrongdoer is unrepentant? Does this not render forgiveness inappropriate? My answer is to agree with those who answer not necessarily. Instead of waiting, perhaps fruitlessly, for an apology, the victim may respond quite differently. They may withhold forgiveness if it is sought or grant forgiveness even if it is not!
Let me explain. The function of forgiveness preserving selfrespect may derive from a number of sources. It may derive from a sort of stoicism wherein one rises above the travails of everyday life, refusing to allow them to hold one's actions and attitudes hostage (Pettigrove 2004:198). This is especially pertinent when the victim of wrongdoing has to determine their response in the face of an unrepentant wrongdoer. Pettigrove maintains that self-respect may derive from the perceived nobility of forgiving the wrongdoer, from one's pride in manifesting what one takes to be a virtue. Moreover, he argues, it may also be affirmed by the forgiver's community to the extent that people see the victim's forgiveness of the unrepentant wrongdoer as a sign of moral strength. In each of these ways forgiving the unrepentant can enhance rather than diminish one's self-respect. If Pettigrove's analysis is correct, then punishment, apology and forgiveness would all seem to function in ways that can block any suggestion of implicit condonation of the unrepentant wrongdoer and sustain the victim's self-respect. They each uphold a moral standard and condemn the actions of the wrongdoer as a violation of that standard, whilst being open to renegotiating relations with him. They each possess qualities that can preserve the victim's self-respect even when it has been challenged by the wrongdoer's misdeeds. And each can function to reduce resentment's hold upon the victim's life.

But what can now be said of non-forgiveness? One reason for introducing this alternative is that the polarities forgiveness and unforgiveness fail to reflect the complexities of human relationships where people and their actions may carry multiple messages and inflict more than one kind of damage at more than one level. Should the victim not be willing to engage the wrongdoer because of the continued presence of certain residual attitudes and emotions, there ought to be no overriding pressures to be brought upon him/her to adopt any specific stance. But even apart from this, third-party witnesses in the form of relatives or community members who are indirectly harmed through their association with a victim may respond in one or other manner indicated. Uniformity of attitude is by no means to be expected on account of such association.

Whether we think that possessing self-respect is a core value or not will depend on whether we think it is always justified to defend it. If we think a person behaves in the way that objective standards demand, and is not merely complacent, we approve of their having the appropriate attitude. Selfrespect is not self-sufficient. It depends on the respectful attitudes of others, or at least on behaviour by others that implies such attitudes towards us. This is why being treated disrespectfully by others undermines our self-respect. No one will dispute that, as a general proposition, the attitudes of others must enter crucially into my self-conception in many instances (Bird 2004:17). How I think and feel about myself will often depend on how others express their thoughts and feelings about me: were this not the case, our relationships with friends, lovers, spouses, parents and mentors would lack their characteristic psychological tension. Moreover, as is 
now widely recognised, practical reflection and evaluation are inherently social or public.

Given this, our sense of our worth will inevitably reflect the social routines that inform and often partly constitute our roles, commitments and personal aspirations. Since those routines include behaviour that is publicly understood to express various attitudes towards us, self-assessment and the assessment of others are bound to be linked in a myriad ways. Sustaining the very particular attitudes to oneself that constitute self-respect requires distinctively respectful treatment from others. Very often our self-conceptions depend on others' attitudes towards us. After all, one could maintain that self-respect has a variety of necessary social preconditions - yet insist that the respect of others is not amongst them. Contrary to this, Rawls (1971:440) claimed that even under ideal conditions, in which everyone is assumed to have had a perfectly healthy and loving upbringing, the continuing reassurance of respect from others is still required for agents to maintain their self-respect. On this view, our selfrespect remains vulnerable to others' disrespect throughout our lives, even under circumstances that are otherwise ideal. Does the respectful or disrespectful behaviour of others ever provide reasons for agents to respect or to lose respect for themselves?

Margalit thinks it does. He contends that:

... [a]lthough self-respect is an attitude you may have toward yourself, it depends on the attitudes of others toward you. This dependence is not merely causal ... [it] is conceptual as well. (Margalit 1994:124)

When, according to Margalit (1994), do the conduct and attitudes of others pose a threat to our self-respect? They do so, he claims, when they involve humiliation and hence disrespect. Thus he defines a 'decent' society as one in which major social institutions do not humiliate its members and a 'civilised' society as one whose members do not humiliate each other. Margalit (ibid:120) understands humiliation as a form of disrespect for humans that supplies 'victims with a sound reason for viewing their self-respect as having been injured'. Given this construal of humiliation, Margalit naturally concludes that decent and civilised societies are the only ones that can fully preserve their members' self-respect. Societies that are in various ways indecent or uncivilised necessarily threaten their members' self-respect by tolerating, and in extreme cases encouraging, acts of humiliation.

In the light of the foregoing, it would seem that forgiveness may not only be inappropriate - it might sometimes even be harmful to one's self-respect. Consider that in the aftermath of genocide it may seem quite ghastly to advocate forgiveness of specific wrongdoers. Only those who have suffered atrocities are entitled to grant forgiveness - when they are dead, no one is entitled to do it for them (Pettigrove 2009:583). But suffering, insult and humiliation go beyond the immediate victims. Sooner or later it falls to the survivors and secondary victims to face the problems of co-existence or enduring enmity (Tück 2004:528). Should they choose to forgive, they would do so not for the sake of the murdered, but for their own. They forgive their own pain, trauma and loss, and shape their new future (Szablowinski 2010:477). Alternatively, should these choose not to forgive, are they diminished by an unforgiving attitude?

In this article I have argued that a victim can regain selfesteem and identity without forgiving the wrongdoer, contrary to the orthodoxy of those who valorise forgiveness. Forgiveness and non-forgiveness are not opposites; they are points along a continuum, and there are many points in between (Safer 1999:183). The argument is that when genuine forgiveness is impossible - because the injury is too great or the offender will not apologise - a better response than resentment is to accept or to work through the injury. This healing process ought to lead to emotional resolution and the ability to move on with one's life. One could ask if it would be appropriate to forgive any repentant wrongdoer without taking into consideration the character and extent of the wrong committed. If an act of forgiveness in the wake of genocide might be demeaning to the victim and related others, it would be understandable not to forgive. Therefore, it is evident that, if victims have suffered extreme humiliation, it may be hard to expect them to forgive even a repentant wrongdoer (Szablowinski 2010:473). The burden of the past wrong may simply be so big that the victim cannot foreswear it without losing moral dignity. Moral dignity is a category of value that is specific to individuals, makes individuals inviolable, puts them 'above all price,' and entitles its bearers to equal standing in a community of equals (Kant [1788] 1998:42-43). Such a community is regulated by moral norms to which all members, as free and rational agents, are accountable. These moral norms express and give substance to the equal dignity of persons, and dictate how they must address and treat one another, what they may properly exact from one another, and what they owe to one another.

Unforgiveness means either doing nothing about the hurt or trying to punish the perpetrator in any way possible. Anger and bitterness caused by the evil deed will occasionally trigger an emotional response, making the condition of the victim worse. The chain of violence and hatred is strengthened and is usually passed on to the next generation. The victims remain victims for life.

Forgiveness, in turn, is difficult and takes time, especially when both decisional forgiveness and emotional forgiveness are at stake. When genuine, it has the power to heal and stop violence. Although it does not remove all pain, it makes whatever pain which remains bearable. Survivors are able to restore their relationships and go on with their lives.

However, non-forgiveness implies continuing to experience both hard negative feelings (retributive non-forgiveness) as well as merely 'soft' ones (non-retributive non-forgiveness). Given the different manners in which people may be victims (primary, secondary, tertiary, etc.) it seems reasonable that 
different responses for different victims of wrongdoing are called for, particularly in cases in which pain and humiliation have been inflicted. In her finely nuanced article, Townley (2011) suggests that the moral work of responding to wrongdoing is not just to forgo anger, but to reconfigure not just repair - our moral communities. Her pluralism in this regard requires some of us to change commitments (and even to betray them); it sometimes requires us to forgive, and sometimes to withhold forgiveness, but it does not always require everyone to take the same stance with respect to a given instance of wrongdoing (Townley 2011:78). Diverse forgiveness stances can be better, more justified, than uniform forgiveness or refusal to forgive. Discussions about the moral value of unconditional forgiveness or whether forgivingness (i.e. the virtue associated with forgiveness - Roberts 1995) should always be commended seem problematic because they seem to be underpinned by a kind of invariance. Whether or not forgiveness is justified may depend greatly on circumstance and context. Forgiveness might lead not only to increased goodwill but also perhaps to trust, which might be unwise, and expose one's vulnerability. Moreover, it might undermine solidarity with others in needful opposition to wrongdoing. It might be a good thing that some people's readiness to forgive is balanced by others' resistance, refusal or reluctance to forgive (Townley 2011:76).

\section{Conclusion}

Emotional responses to perceived wrongs justify different responses. Staying calm and emotionless in the face of serious wrongdoing seems more vicious than virtuous since such a response misses a sense of the importance of what has happened and its significance to the people affected. Our emotions aim at restoring the victim to the community and creating a sense of meaning in the events. When inflicting harm upon victims, offenders effectively convey a message that they are superior to the victims because they can do such things without feeling the need to restrain themselves. As a means of effecting moral repair (especially to their self-respect) those offended are morally mandated to demand justice.

Although forgiveness is one of several ways to overcome a past wrong, it is not the only ethical response to wrong and evil deeds. To demand forgiveness as the only possible way may often have worse moral outcomes and violate more ethical principles (e.g. respect for human dignity, freedom and responsibility) than retaining feelings of resentment towards wrongdoers. Of course, choosing to forgive brings about a change in the victim's emotional responses to wrongdoing. It is likely that angry and embittered responses to human rights violations, for example, may be overcome if wrongdoers are forgiven. Likewise, non-retributive emotions will remain, especially if they are not eliminated by forgiveness; but with time even memories of hurt fade unless deliberately cultivated.

When forgiveness is granted, it does not mean that the evil deeds are excused (treated as if they had a sufficient explanation for being committed), condoned (accepted as wrong but still being within the margin of tolerance) or forgotten (wiped out from the memory), as many supporters of unforgivability seem to fear. Forgiveness deals with the issue of how the deeds will be remembered: without feelings of hatred and resentment. Likewise, I have argued that non-forgiveness is not the opposite of forgiveness. It may (in one of its forms) share with forgiveness the presence of certain non-retributive attitudes or emotions that play different roles in circumscribing the boundaries of victims' self-respect.

Victims and bystanders experience a number of emotions in the aftermath of conflict: grief, sorrow, hurt, shock - as well as disappointment, anguish, mistrust, despair. With renewed focus upon the affective dimensions of wrongdoing, philosophers have begun revaluing reactive attitudes, both retributive and non-retributive. Indeed, if the better-known retributive reactive attitudes are important indicators of selfrespect, the lesser-known non-retributive ones also deserve appropriate acknowledgment for their roles in defence of it.

\section{Acknowledgements Competing interests}

The author declares that he has no financial or personal relationship(s) that may have inappropriately influenced him in writing this article.

\section{References}

Allais, L., 2008, 'Wiping the slate clean: The heart of forgiveness', Philosophy and Public Affairs 36(1), 33-68. http://dx.doi.org/10.1111/j.1088-4963.2008.00123.x

Ally, M., 2005, 'The moral appropriateness of shame', Koers - Bulletin for Christian Scholarship 70(2), 287-305. http://dx.doi.org/10.4102/koers.v70i2.269

Bird, C., 2004, 'Self-respect and the respect of others', European Journal of Philosophy 18(1), 17-40. http://dx.doi.org/10.1111/j.1468-0378.2008.00332.x

Blustein, J., 2010, 'Forgiveness, commemoration, and restorative justice: The role of moral emotions', Metaphilosophy 41(4), 582-617. http://dx.doi.org/10.1111/j.14679973.2010.01652.x

Dillon, R., 1997, 'Self-respect: Moral, emotional, political', Ethics 107, 226-249. http:// dx.doi.org/10.1086/233719

Griswold, C., 2007, Forgiveness: A philosophical exploration, Cambridge University Press, New York. http://dx.doi.org/10.1017/CBO9780511619168

Hampton, J., 1988, 'Forgiveness, resentment and hatred', in J.G. Murphy \& J. Hampton (eds.), Forgiveness and mercy, pp. 35-87, Cambridge University Press, Cambridge. http://dx.doi.org/10.1017/CBO9780511625121.004

Holmgren, M.R., 1993, 'Forgiveness and the intrinsic value of persons', American Philosophical Quarterly 30(4), 341-352.

Hughes, P., 1997, 'What is involved in forgiving?', Philosophia 25, 33-49. http://dx.doi. org/10.1007/BF02380023

Kant, I., [1788] 1998, Groundwork of the metaphysics of morals, M. Gregor \& J. Timmermann (eds.), Cambridge University Press, Cambridge.

Lamb, S., 2006, 'Forgiveness, women and responsibility to the group', Journal of Human Rights 5, 45-60. http://dx.doi.org/10.1080/14754830500485874

Luchies, L.B., Finkel, E.J., Mcnulty, J.K. \& Kumashiro, M., 2010, 'The doormat effect: When forgiving erodes self-respect and self-concept clarity', Journal of Personality and Social Psychology 98(5), 734-749. http://dx.doi.org/10.1037/a0017838, PMid:20438221

MacLachlan, A., 2009, 'Forgiveness and moral solidarity', in S. Bloch-Schulman \& D. White (eds.) Forgiveness: Probing the boundaries, pp. 3-16, Inter-Disciplinary Press, Oxford.

Margalit, A., 1994, The decent society, Harvard University Press, Cambridge.

Murphy, J.G., 1988, 'Forgiveness and resentment', in J.G. Murphy \& J. Hampton (eds.), Forgiveness and mercy, pp. 14-34, Cambridge University Press, Cambridge. http:// dx.doi.org/10.1017/CBO9780511625121, PMid:3272746

Murphy, J.G., 2003, Getting even: Forgiveness and its limits, Oxford University Press, New York.

Pettigrove, G., 2004, 'Unapologetic forgiveness', American Philosophical Quarterly 41(3), July, 187-204.

Pettigrove, G., 2009, 'The standing to forgive', The Monist 92(4), 583-603. http://dx.doi. org $/ 10.5840 /$ monist200992432 
Radzik, L., 2011, 'Moral bystanders and the virtue of forgiveness', in G. Karabin \& K. Wigura (eds.), Probing the boundaries: Forgiveness: Promise, possibility \& failure, pp. 197-204, Inter-Disciplinary Press, Oxford.

Rawls, J., 1971, A theory of justice, Harvard University Press, Cambridge. PMCid:PMC2609853 Richards, N., 1988, 'Forgiveness', Ethics 99(1), 77-97. http://dx.doi.org/10.1086/293036 Roberts, R.C., 1995, 'Forgivingness', American Philosophical Quarterly 32(4), 289-303.

Rosebury, B., 2008, 'Respect for just revenge', Philosophy and Phenomenological Research 77(2), 451-471. http://dx.doi.org/10.1111/j.1933-1592.2008.00198.x

Safer, J., 1999, Forgiving and not forgiving: Why sometimes it's better not to forgive, Harper Perennial, New York. PMCid:PMC1220702

Shapiro, D.L., 2002, 'Negotiating emotions', Conflict Resolution Quarterly 20(1), 67-82. http://dx.doi.org/10.1002/crq.11
Szablowinski, Z., 2010, 'Between forgiveness and unforgiveness', Heythrop Journal 51(3), 471-482. http://dx.doi.org/10.1111/j.1468-2265.2009.00531.x

Taylor, G., 1985, 'Pride, shame and guilt: Emotions of self-assessment', Clarendon Press, Oxford.

Townley, C., 2011, 'Forgiveness and betrayal', in G. Karabin \& K. Wigura (eds.), Probing the boundaries: Forgiveness: Promise, possibility \& failure, pp. 71-81, Inter-Disciplinary Press, Oxford.

Tück, J-H., 2004, 'Unforgivable forgiveness? Jankélévitch, Derrida, and a hope against all hope', Communio 31(4), 522-539.

Turner, F., 1995, 'Shame, beauty and the tragic view of history', American Behavioral Scientist 38, 1060-1075. http://dx.doi.org/10.1177/0002764295038008003

Walker, M.U., 2006, Moral repair: Reconstructing moral relations after wrongdoing, Cambridge University Press, New York. http://dx.doi.org/10.1017/CBO9780511618024 